綜＼cjkstart説 (Review Article)：膜 (MEMBRANE), 12 (5), 261- 271 (1987)

\title{
生体膜のラテラル方向のダイナミックス構造解析
}

\author{
辻明彦 \\ 浜松ホトニクス 研究部 $\mathbf{T} 435$ 浜松市市野町 1126-1
}

\section{Analysis of Lateral Dynamic Structure of Biomembranes}

\begin{abstract}
Akihiko T suJI
Hamamatsu Photonics K.K., Research Division, 1126-1 Ichino-cho, Hamamatus 435

Proteins are capable of lateral and rotational motion in lipid bilayer membranes. Lateral diffusion of membrane proteins has been studied mainly by the fluorescence photobleaching recovery (FPR) technique, and rotational diffusion by the technique of anisotropy decay of "triplet probes" bound to proteins or by the technique of saturation transfer electron spin resonance (ST-ESR). From these results, it has become clear that motion of proteins in lipid bilayer membranes can be well described as that of a cylindrical particle in a two-dimensional matrix with a viscosity of a few poise.

However, the protein mobility in cell plasma membranes is, in many cases, largely restricted. This restriction would be due to the interaction of the integral protein with the cytoskeletal proteins. As an example, lateral and rotational motion of an anion channel protein band 3 , in human erythrocyte membrane is described. In this case, it is suggested that there are two kinds of restriction/regulation mechanisms. One is the anchoring of band 3 to the cytoskeletal protein network, the other is the trapping in a compartment formed with the cytoskeletal proteins. Based on these studies, the character of lateral dynamics of proteins in biomembranes is disucussed.
\end{abstract}

Key Words: Membrane protein, Lateral diffusion, Rotation, Oligomeric structure, Cytoskeletal protein

1. はじめに

2. ラテラル方向のダイナミックスの測定法
$2 \cdot 1$ ラテラル方向の移動速度
$2 \cdot 2$ 回転運動
$2 \cdot 3$ 複合体・会合体形成

3. 赤血球膜におけるバンド 3 タンパク質の lateral motion 之回転運動：裏打ち構造体による制御
$3 \cdot 1$ アンキリンの役割り
$3 \cdot 2$ スペクトリンの 4 量体 22 量体変換の影響
$3 \cdot 3$ バンド 3 の細胞質側ドメインと裏打ち構造体と の相互作用
$3 \cdot 4$ 董打ち構造体による制御機構

4. おわりに一泣ラル方向の構造の動的な変化
1. はじめに

生体膜において, タンパク質, 脂質など膜を構成して いる分子は，いろいろなモードの熱運動を行っている. 膜タンパク質を例にとると，回転運動をしながらラテラ ル方向に拡散している，乙れらの運動は，基本的に，リ ン脂質層を厚さ $\mathrm{h}$ と粘性 $\mu$ をあつ平面シートとしたとき の円柱状粒子のブラウン運動で表わされる (Saffman Delbruck のモデル, Fig. 12) ${ }^{2)}$ ）しかしながら，タンパ ク質が生体膜上を動く速さはいつ屯同じではない.とき には速く，ときには動かなくなる．動く方向もランダム ではなく，膜上の特定部位に集まることがある．また， タンパク質分子間での会合体・複合体の形成や解離屯起 


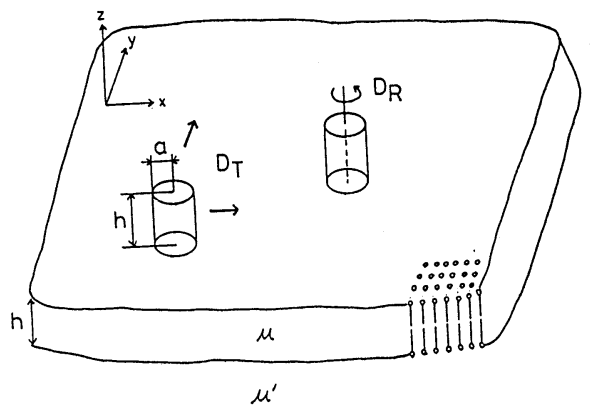

Fig.1 膜に抢けるタンパク質の運動（SaffmanDelbrück ) ${ }^{2)}$

膜タンパク質を半径 $a$, 長さ $h$ の円柱で表わ した.

$h ;$ リン脂質層の厚さ, $\mu$; 粘性 $\mu^{\prime} ;$ 水の粘性.

$D_{T}$ (ラテラル方向の拡散定数 $), D_{R}$ (回転拡 散定数) は,

$$
\begin{aligned}
& D_{T}=\frac{k T}{4 \pi \mu h}\left(\log \frac{\mu h}{\mu^{\prime} a}-r\right) \\
& D_{R}=\frac{k T}{4 \pi \mu a^{2} h}
\end{aligned}
$$

$k$; ボルッマン定数 $r$; オイラー定数 $T$; 絶 対温度で表わされる。 また，

$$
D_{\mathrm{T}} / D_{R}=\left(\log \frac{\mu h}{\mu^{\prime} a}-\gamma\right) \cdot a^{2}
$$

きている. てのようなラテラル方向の動的な構造変化は, 生体膜の大きな特徵であり, 膜がさまざまな機能を果た していく上で大きな役割を荷っていると考えられる.

本稿では, ラテラル方向のダイナミックスとして, 並 進拡散 (lateral diffusion), 回転運動 (rotational diffusion), 膜タンパク質の複合体・会合体形成をとりあ げる. まず, 測定法の簡単な説明とそこから得られる膜 の動的状態の基本的性質について述べる. 生体膜では, 乙の「基本的性質」がタンパ質間相互作用 (膜タンパ ク質間あるいは膜タンパク質と細胞内に存在するタンパ ク質との間)によって修飾されており,てれが, 膜タンパ ク質の振舞いや膜の局所的構造を決めていると考えられ る. その例として, 赤血球膜をとりあげ, 著者らの研究 を中心に述べる。

\section{2. ラテラル方向のダイナミックスの測定法}

\section{1 ラテラル方向の移動速度}

2.1.1 虽光退色回復法 (Fluorescence Photobleaching Recovery, FPR)

ラテラル方向の動きを測定するとき，広く使われてい
A

a

b

C

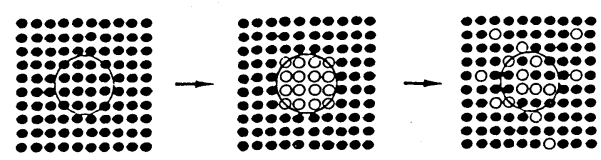

B

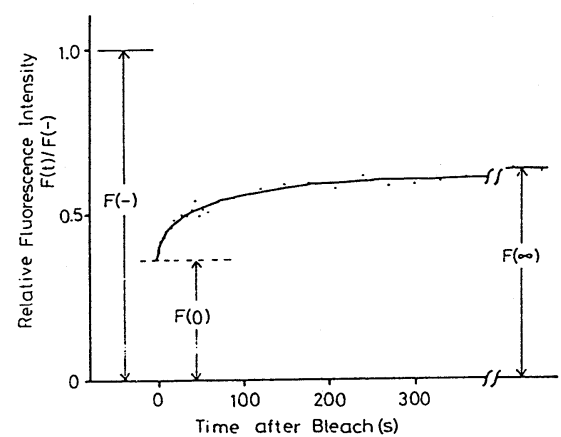

Fig. 2 蛍光退色回復法 (FPR)

$\mathrm{A}$; 測定原理を模式的に表わした

蛍光分子 $\bigcirc$ 光退色した分子

円はレーザースポットを表わす。

B; ヒト赤血球細胞膜において, アニオンチ ヤネルタンパク質バンド 3 をFITCでラ ベルしたときの FPR カーブ $\left(26^{\circ} \mathrm{C}\right.$, in 5 $\mathrm{mM} \mathrm{Na}_{2} \mathrm{HPO}_{4} / \mathrm{NaH}_{2} \mathrm{PO}_{4}, 10 \mathrm{mM} \mathrm{NaCl}$ $\mathrm{pH} 7.8)$

$F(-), F(0), \mathrm{F}(\infty)$ はそれぞれ，退色前， 退色直後, 退色後無限時間後の蛍光強度 を表わす。

mobile $\left(\frac{F(\infty)-F(0)}{F(-)-F(0)}\right) ; 40 \%$

拡散定数; $5.3 \times 10^{-11} \mathrm{~cm}^{2} / \mathrm{s}$

る方法は, 蛍光退色回復法である ${ }^{3 \sim 57}$. 測定原理と回復 カーブの模式図をFig. 2 亿示す.タンパク質または脂質 を蛍光試薬でラベルしたのち, 顕微鏡下で直径 $1.5 〜 4.0$ $\mu \mathrm{m}$ のレーザースポットを生体膜上にあて，スポット内 の蛍光強度を測定する．短時間 ( 100ミリ秒) 強い光を あててスポット内の大部分の蛍光分子を光退色 (photobleach) させたのち (Fig. $2 \mathrm{~A}-\mathrm{b}$ ), 弱い光 (退色光の 1/3000 以下) をあててスポット内の蛍光強度が回復して くるのをモニターする (Fig. $2 \mathrm{~A}-\mathrm{c}$ ). 蛍光強度の回復 は, スポット内の退色した分子とスポット外の蛍光分子 がともにラテラル方向に運動しているてとにより起てる. 光退色後の回復の大きさ $[F(\infty)-F(0)] /[F(-)-F(0)]$ から動いている成分 (mobile component) の比率が, 回復の速さから移動速度が求まる. 移動が拡散によると き, 回復曲線は, 

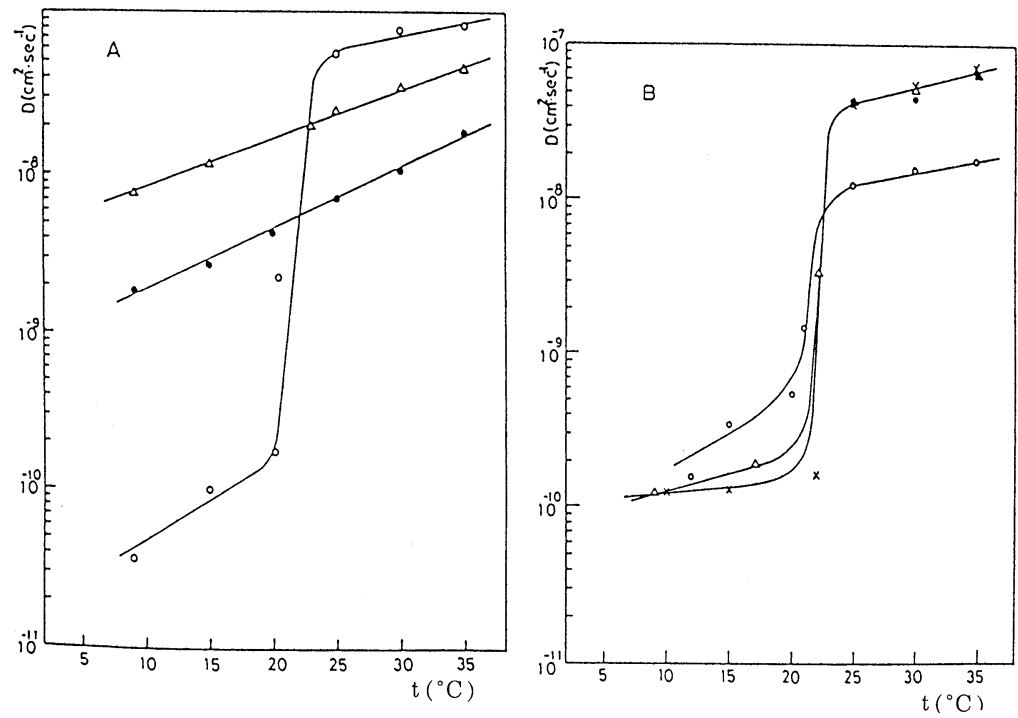

Fig. 3 リポソームにおける, 脂質・タンパク質の拡散速度 ${ }^{6}$.

A は, リン脂質プローブ NBD-PE の拡散速度の, 温度依存性, 脂質組成依存性を示す.

$\bigcirc \mathrm{DMPC}, \bigcirc \mathrm{DMPC}-$ コレステロール $(1: 1), \triangle$ 赤血球膜総脂質 (不飽和脂肪酸, コレス テロールを含む)

B は, DMPC中のタンパク質の拡散速度の温度依存性を示す．

○バンド 3

NBD-PE : N-(4-nitro-2, 1, 3-benzoxadiazolyl)-phosphatidylethanolamine

DMPC : dimyristoylphosphatidylcholine

$$
\begin{aligned}
F(t) / F(-)= & x_{1} \sum_{n}^{\infty}\left[(-K)^{n} / n !\right][1+n(2 t / \tau)]^{-1}+ \\
& \left(1-x_{1}\right) K^{-1}\left(1-e^{-K}\right)
\end{aligned}
$$

$F(t)$ : 退色後, 時間 $t$ 亿打ける蛍光強度, $F(-)$ : 退色前 の蛍光強度, $x$ : mobile の成分の比率, $K$ : 退色の大きさ $[F(0) / F(-)]$ により決まる定数, で表わされる. 1 項目が 速さてで動いている成分， 2 項目が動いていない成分 (immobile component) である. $\tau$ は, 拡散定数 $D_{T}$ (lateral diffusion coefficient) と,

$$
D_{T}=W^{2} / 4 \tau
$$

の関係がある (wは,レーザースポットの半径). Mobile 成分が多成分系のときには, 各成分の回復カーブを足し 合わせたあのになる.

この測定法では，分子がある一定距離 (スポットの大 きさに相当する距離) を移動するのに要する時間を測定 している.その距離は, 100倍の対物レンズ使用時で 0.5 $0.8 \mu \mathrm{m}$ 程度であるが, 乙れは細胞膜上での移動距離とし てはかなり大きい. Immobile 成分とは, 拡散速度が非 常に遅いあの (100倍対物レンズ使用時, $D_{T}<10^{-13} \mathrm{~cm}^{2} / \mathrm{s}$ ), あるいはスポットの大きさに相当する距離を移動しない あのである.

人工膜に打ける測定例を Fig. 3 亿示す ${ }^{6)}$. A はリン脂
質の蛍光プローブ NBD-PE を測定したものである.液晶 相に扔いては, $D_{T}=10^{-9} \sim 10^{-8} \mathrm{~cm}^{2} / \mathrm{s}$ のオーダーの拡 散速度を屯ち, 速さは脂質組成 (脂肪酸の飽和度, コレ ステロール含量など）により変化する. DMPCリポソー 厶中での $23^{\circ} \mathrm{C}$ 付近での急激な変化は, 固相 $\rightleftarrows$ 液晶相の 相転移に対応したものである. 固相に扔いては, 液晶相 と比較して運動性が 1000 倍近く減少する．Bは, タンパ ク質の測定例であるが，拡散速度は脂質とあまり差がな い.乙れは, Saffman-Delbruck のモデル (Fig. 1, 拡散 速度は脂質の粘性と温度には 1 次の依存性をむつが，分 子の大きさには強くは依存しない）功予測されること とよく一致している.乙れらの測定に扔いては, 蛍光強 度はほぼ $100 \%$ 回復し,すべての分子が同じ拡散速度で 動いているととが示された。

\section{2・1.2 衝突頻度 (collision rate) の測定}

FPR の測定には, 試料がレーザースポットと比べて十 分に大きいととが必要であり，小さなべシクル（直径く $4 \mu \mathrm{m})$ には適用できない. このような試料におけるlateral mobility を調べるときには, 衝突頻度を測定することが 有力な方法である。また, FPR 法が広い範囲に扔ける移 動性をみているのに対し, 衝突頻度の測定はより微小な 
領域内での運動性をみるととになり, lateral mobility に対して相補的な情報を与える.

しかしながら, 衝突頻度を測定する方法は現在のとて ろ確立されて抢らず, 今後の発展が望まれる. ESR (電 子スピン共鳴) 法に扔いて, スピン交換を利用して測定 する試みがなされており, リポソームや赤血球膜での脂 質の拡散速度が求められている ${ }^{7,8)}$. 同法を膜タンパク質 の拡散の測定に適用するてと屯試みられている ${ }^{9)}$. こて では文献を示すにとどめる. また, 膜タンパク質・脂質 を蛍光・りん光プローブまたはそれに対する消光剤 (quencher) で各々ラベルし, 蛍光 (りん光) 消光の測 定から衝突頻度を求める方法も有力であると考えられる.

\section{$2 \cdot 2$ 回転運動}

膜タンパク質はFig. 1 亿示すように, 膜法線方向軸を 中心に異方的な回転運動を行っている. 乙の速さを測定 する方法として, 蛍光・りん光の異方性 (anisotropy) を利用するあのと, 飽和移動 ESR 法とがある.

\section{$2 \cdot 2 \cdot 1$ 偏光解消法}

個々の蛍光分子は, 吸収や発光に対する “軸 (遷移モ ーメント)”をむっている. 蛍光分子の集団を偏光した光 で励起したとき, 励起光と平行方向に遷移モーメントを あつ分子が選択的江励起される. 励起光 $A$ 之分子の遷移 モーメントとのなす角度を $\alpha$ とすると, その分子が励起 される確率は, $\cos ^{2} \alpha$ に比例する. 乙のため, 基底状態 および励起状態での分子の遷移モーメントの分布に偏よ りが生じ, その後の吸収や蛍光の強さは異方性をむつ.

異方性 $r$ は, $r=\left[I-I_{+}\right] /\left[I+2 I_{+}\right]$

$I$; 励起光之平行方向の蛍光 (吸収) の強さ

$I_{+}$; 励起光之垂直方向の蛍光 (吸収) の強さ で定義される. 異方性は, 分子の回転運動により, 時間 ととあに減衰していく，したがって, 吸収や蛍光の異方 性の減衰を調べることで, その分子の回転の速さを知る ことができる (偏光解消法) ${ }^{10,11)}$.

膜タンパク質が Fig. 1 亿示すような回転運動をしてい るとき, 異方性の減衰 $\mathrm{r}(\mathrm{t})$ は,

$$
\begin{gathered}
r(t)=r_{1} \exp \left(-D_{/ /} / t\right)+r_{2} \exp \left(-4 D_{I /} / t\right)+r_{\infty} \\
r_{1}=\frac{6}{5} \cdot \sin ^{2} \theta \cdot \cos ^{2} \theta, \quad r_{2}=\frac{3}{10} \sin ^{4} \theta, \\
r_{\infty}=\frac{1}{10}\left(3 \cos ^{2} \theta-1\right)^{2}
\end{gathered}
$$

$\theta$; 膜法線 (回転軸) と遷移モーメントとがつくる角度

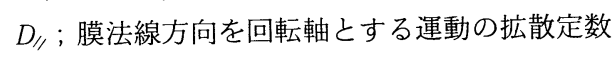

で表わされる ${ }^{37)}$. 回転運動が等方的でないため, 無限時

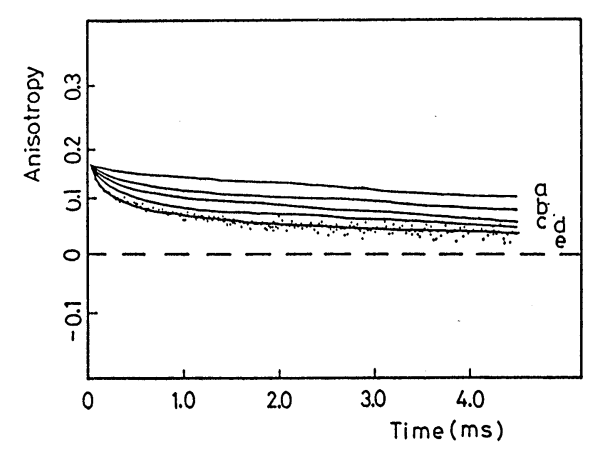

Fig. 4 り九光の異方性の減衰カーブ 赤血球膜に损いて,バンド 3 亿結合させたエ オシン -5- マレイミドからのりん光の異方性 の減衰.

a ; $20^{\circ} \mathrm{C}, \mathrm{b} ; 26^{\circ} \mathrm{C}, \mathrm{c} ; 30^{\circ} \mathrm{C}, \mathrm{d} ; 37^{\circ} \mathrm{C}$, e ; $42^{\circ} \mathrm{C}$.

in $5 \mathrm{mM} \mathrm{Na}_{2} \mathrm{HPO}_{4} / \mathrm{NaH}_{2} \mathrm{PO}_{4}, 10 \mathrm{mM} \mathrm{NaCl}$, pH7.8.

間後む一定量の異方性 $\left(r_{\infty}\right)$ が残る. 測定例を Fig. 4 亿 示す，温度が上がるにつれて異方性の減衰が速くなり, 回転が速くなるととがわかる.乙れらのカーブは, 式 [6] には適合せず, 便宜上式〔7〕を用いて解析した. $r(t)=R_{1} \exp \left(-t / \tau_{1}\right)+R_{2} \exp \left(-t / \tau_{2}\right)+R_{3} \quad[7]$ $R_{1}, R_{2}, R_{3}, \tau_{1}, \tau_{2}$ をパラメータとし, 回転の速さは便 宜上, 回転相関時間 (rotational correlation time) $\tau$ で表わす.

このてとは, バンド 3 タンパク質の回転には, 少なく とも速さの異なる成分が 2 つまたは 3 つ存在するてとを 示している $\left(R_{3}\right.$ は, $r_{\infty}$ と 5 ミリ秒の時間スケールでほ とんど減衰しない非常に遅い成分からの異方性との和で ある).

この方法が検出する運動の時間スケールは, 用いる蛍 光プローブの励起状態での寿命 (life time, $\phi$ ) により決 まる.打よそ $1 / 100<\tau / \phi<10$ の範囲で測定するてとが できる. たとえば, プローブとしてエオシン $(\phi=2.6 \mathrm{~ms})$ を用いたときには， $20 \mu \mathrm{s}<\tau<20 \mathrm{~ms}$ の範囲である.

\section{$2 \cdot 2 \cdot 2$ 飽和移動 ESR 法}

ニトロキシドラジカル $(\mathrm{N}-\mathrm{O} \cdot)$ ) $\mathrm{ESR}$ スペクトルを 測定することにより, 膜の中でのタンパク質や脂質の動 きをモニターするてとができる(スピンラベル法) ${ }^{12,13)}$. タンパク質にラジカルを含む試薬 (スピンラベル) を結 合させる. ESR の吸収が部分的に飽和を起てすように強 いマイクロ波を照射した状態で, 2 次微分吸収スペクト ルの $90^{\circ}$ 位相の遅れた成分をとる. スペクトル上のパラ 
メータから回転相関時間(rotational correlation time) $\tau_{c}$ が求まる (飽和移動法 $)^{14,15)}$. 乙の方法は, スピン緩 和において，スピンー格子緩和と回転運動による緩和と の速さの相対的な比率により，スペクトルが変化するこ とを利用したあのである。 ニトロキシドラジカルのスピ ン-格子緩和時間は $10^{-5} \mathrm{~S}$ の值をもつため, $10^{-3}<\tau_{c}<$ $10^{-7} \mathrm{~s}$ の速さの回転運動を検出するてとができる.また, 速さの異なる 2 成分以上が存在しているときには，それ らを「平均化」した $\tau_{c}$ を与える. 測定例をFig. 5 亿示す ${ }^{16)}$. 回転相関時間は, $H^{\prime} / H=1.0$ の之き $\tau_{c}=400 \mu \mathrm{s}$, 0.65 のとき $73 \mu \mathrm{s}$ である. バンド 3 の回転速度は, DMPC の相転移に対応して変化している (Fig. 3B 屯参照).

\section{3 複合体・会合体形成}

膜タンパク質は, 2 量体・3 量体などの会合体 ( oligomer) や, 他のタンパク質との複合体をつくりやすい. 複合体・会合体形成を，直接検出・測定することはあま り試みられていない.Fig.1，式 [3] から明らかなように, 回転運動の速さは, 分子の大きさ (半径) に大きく依存 するため, 回転速度の変化を測定することで, 複合体形 成や会合状態の変化を検出・推定するてとが行われてい る ${ }^{17 \sim 20)}$.

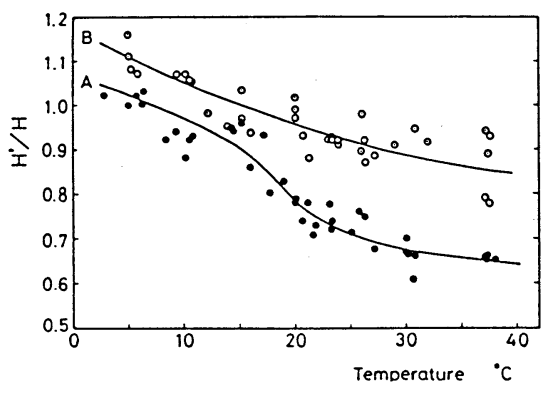

Fig. 5 飽和移動 ESR 法による, バンド 3 の回転運 動の速さの測定 ${ }^{16)}$

バンド 3-DMPC 再構成膜において, バンド 3 をスピンラベルレ, 飽和移動 ESR スペク トルを測定した (○)。縦軸の $\mathrm{H} \cdot / \mathrm{H}$ は，ス ペクトル上のパラメータで回転運動の速さ を反映する(大きいほど遅い)

○は, 裹打ちタンパク質(アンキリン,スペ クトンン，バンド 4.1 , アクチン) を加えた ときの結果で,てれらのタンパク質の結合に より, バンド 3 の回転が, 液晶相 $\left(23^{\circ} \mathrm{C}\right.$ 以 上）で約 2.5 倍遅くなることを示している.

\section{3 赤血球膜におけるバンド3タンパク質の lateral} motion と回転運動 : 裏打ち構造体による制御

膜タンパク質のふるまいは, ラテラル方向の移動速度, 回転運動, 会合体・複合体形成などを個別に測定し, そ れを総合することで推定できる.

人工膜(再構成膜)に执いては, これらの関係がSaffmanDelbruck のモデル (Fig. 1) で説明できるてとが示され ている ${ }^{40)}$ 。たとえば，バンド 3 の運動は DMPC中にお いて, $D_{T}=8 \times 10^{-8} \mathrm{~cm}^{2} / \mathrm{s}, D_{R}=4 \times 10^{4} \mathrm{~s}^{-1}$ (Fig. 3, $5)$ であり, 式 [3] の関係をみたす ${ }^{16)}$. また，桿体視細 胞のタンパク質ロドプシンの再構成膜において, 脂質と タンパク質との比率 (lipid/protein) を下げていくと回 転が遅くなるが，乙れはロドプシンが，より大きな会合 体をつくるためであると考えられる199.

一方，生体膜における膜タンパク質の挙動は, Fig. 1の 関係で表わされないことがある. バンド 3 の赤血球膜中 での拡散は， $D_{T}=5.3 \times 10^{-11} \mathrm{~cm}^{2} / \mathrm{s}$ で動く成分が $40 \%$, immobile 成分が $60 \%$ である $\left(26^{\circ} \mathrm{C}\right.$, in $5 \mathrm{mM} \mathrm{Na}_{2} \mathrm{HPO}_{4} /$ $\left.\mathrm{NaH}_{2} \mathrm{PO}_{4}, 10 \mathrm{mM} \mathrm{NaCl} \mathrm{pH} 7.8\right)^{25)}$. NBD-PEの拡 散速度 $\left(2.5 \times 10^{-9} \mathrm{~cm}^{2} / \mathrm{s}\right)$ から予想されるバンド 3 の $D_{T}$ は $5 \times 10^{-10} \sim 1 \times 10^{-9} \mathrm{~cm}^{2} / \mathrm{s}$ である，また，偏光解消 法から得られた回転運動の速さは，バンド 32 量体に対

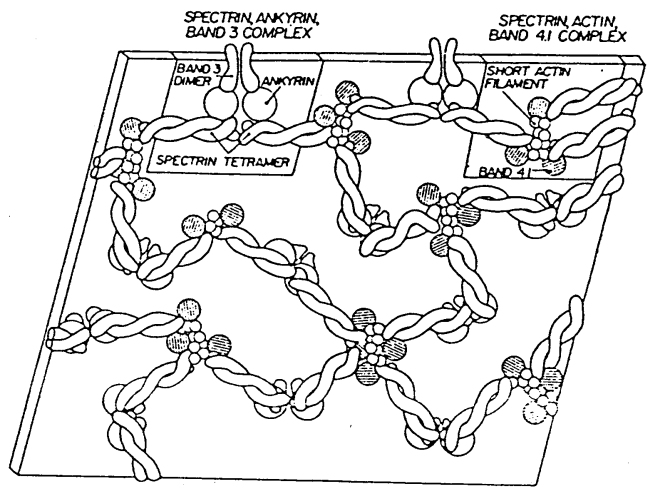

Fig.6 赤血球膜裏打ち構造体 (Lux, S. E. ${ }^{29)}$ ) 裹打ち構造体は,アンキリン,スペクトリン 2 量体, バンド 4.1 アクチンで構成される. これらはスペクトリン 2 量体間の head to head様式の結合による 4 量体の形成, スペ クトリン 2 量体の尾部領域でのバンド 4.1 , アクチンとの結合により, 網目状にネットワ 一クをつくる. また，アンキリン，細胞膜 にあたるアニオンチャネルタンパク質バンド 3 とスペクトリンの両方に特異的に結合す る性質を持つ。 

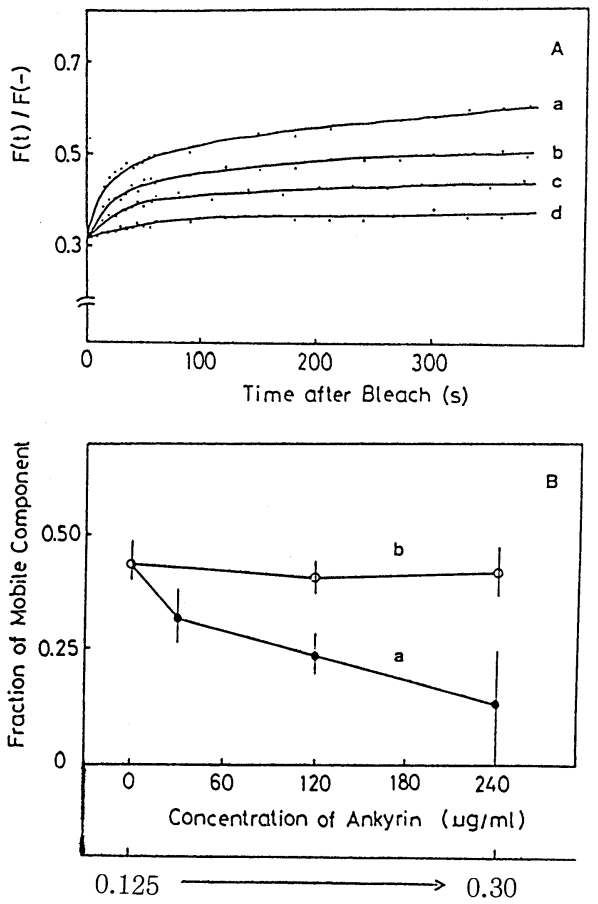

Ankirin/band 3 in erythrocyte membrane

Fig. 7 バンド 3 の lateral motion に与えるアンキ リンの効果 ${ }^{25}$

赤血球膜ゴーストに精製したアンキリンを加 えたときの FPR カーブの変化を調べた.

$\mathrm{A}$; 加えるアンキリンの量が増えるにつれて, $\mathrm{a} \rightarrow \mathrm{b} \rightarrow \mathrm{c} \rightarrow \mathrm{d}$ へと変化していく.

B ; mobile 成分の比率をプロットした。

$\mathrm{b}($ ○) は, 熱失活させたアンキリンを加 えたとき.

して, $D_{R}=10^{4} \mathrm{~s}^{-1}$ のオーダーであると推定され, $D_{\mathrm{T}}$ と $D_{R}$ の関係は式 [3] を満足しない (ラテラル方向の移動速 度が小さい). このようなラテラル方向の移動速度の制 限・制御は, 膜の細胞質側表面に網目状に存在する構造 物 (裏打ち構造体, Fig. 6) ${ }^{27 \sim 29)}$ により行われている ${ }^{21 \sim ~}$ 26). 裏打ち構造体は数種類のタンパク質—アンキリン, スペクトリン, バンド 4.1 , アクチン—の複重合体で ある.

赤血球膜の裹打ち構造体と類似の構造物は, 他の細胞 に拉ても広く存在していると考えられる.アンキリン, スペクトリン, バンド 4.1 類似のタンパク質が, 多くの 細胞の膜細胞質側表面に存在する ${ }^{30 \sim 32)}$. また, 細胞内フ ィラメントは, 膜と接触していることが知られている.

このようなとき,「タンパク質間相互作用により,膜夕
ンパク質の挙動がどのように変化するか, その結果, ラ テラル方のオーガニゼーションがどのようにコントロ ールされるか」が問題である. 以下にこの問題への取り くみ・解析の例として, 赤血球膜におけるバンド 3 の運 動性と裏打ち構造体との関わり合いをとりあげる ${ }^{25,26)}$.

\section{$3 \cdot 1$ アンキリンの役わり}

バンド 3 は,アンキリンにより裏打ち構造体に結びつ けられている，アンキリンは，バンド 3 とスペクトリン の両方にそれぞれ 1:1の比率で結合する. ただし, アン キリンの存在量は, バンド 3 の 10 15\% (モル比) であ る33).

赤血球膜ゴーストに，精製したアンキリンを加えたと きの FPR カーブの変化を Fig. 7 に示した. Mobileなバ

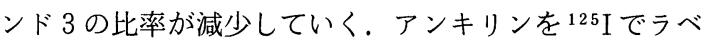
ルし，ゴーストへの結合量を調べると，結合は特異的で あり, 実験条件下で最大アンキリン/バンド $3=0.17$ (あ とから存在する量を合わせるとアンキリン/バンド $3=0.30$, モル比)であった．乙のとき mobile 成分は $12 \%$ である. 熱失活させたアンキリン (バンド 3 への特異的結合能を 失なっている) を加えたときには, FPR カーブには変化 はみられなかった ( Fig. 7Bb). 以上の結果から,アンキ リンと結合したバンド 3 は immobileであり, 結合して いないバンド 3 が mobile $\left(D_{T}=5.3 \times 10^{-11} \mathrm{~cm}^{2} / \mathrm{s}\right)$ であ ると考えられる.アンキリン/バンド 3 が 10 ア $15 \%$ のと き, immobile の比率が $60 \%$ であるのは, バンド 3 が 2 量体， 4 量体，……よ゙の会合体をつくることによる ${ }^{38,391}$ と考えられる.

\section{$3 \cdot 2$ スペクトリンの 4 量体 $\rightleftarrows 2$ 量体変換の影響}

スペクトリンは裏打ち構造体の主要構成タンパク質で ある．スペクトリンを欠くマウス赤血球変異株では，バ ンド 3 のラテラル方向の拡散速度が正常なむのよりあ 50 倍速い ${ }^{21)}$. スペクトリンは, へテロ 2 量体を単位とする 棒状の分子で, head to head の結合により 4 量体をつ くる. 4 量体と 2 量体との平衡状態は, 赤血球膜に結合 した状態および溶液中において, イオン強度，ポリアミ ンの存在など種々の条件により変化する ${ }^{25,34,35)}$.

Fig. 8 は，ポリアミンを加えたときのスペクトリンの 4 量体と 2 量体との比率の変化を表わしたものである. ポリアミン存在下 $(10 \mathrm{mM} \mathrm{NaCl})$ でゴーストを $37^{\circ} \mathrm{C} 20$ 分間インキュベーションしたのち, $4^{\circ} \mathrm{C}$, 低イオン強度 (0.3 $\mathrm{mM} \mathrm{Na}_{2} \mathrm{HPO}_{4} / \mathrm{NaH}_{2} \mathrm{PO}_{4}, 0.2 \mathrm{mM}$ EDTA pH7.6) で 20 時間処理し,スペクトリンとアクチンを遊離させる. ショ糖密度勾配遠心により，スペクトリン 4 量体と 2 量 

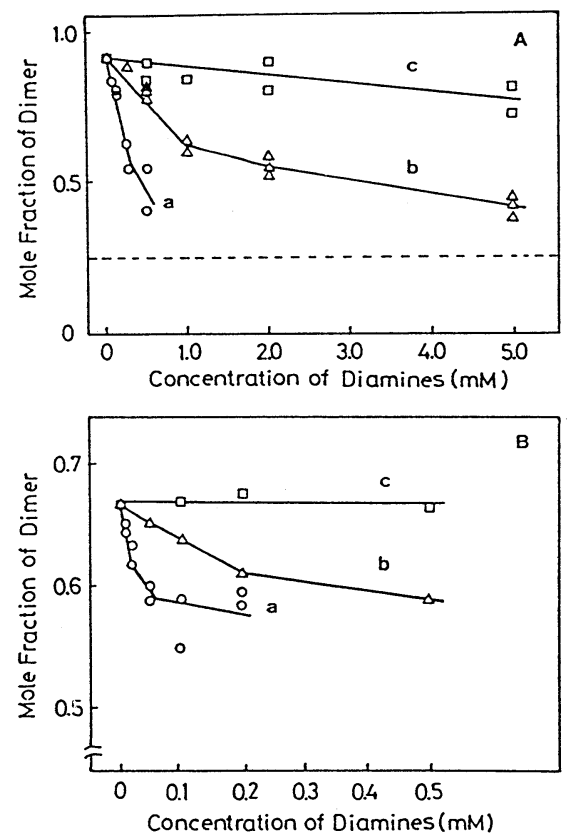

Fig. 8 ポリアミンによる,スペクトリンの 4 量体と 2 量体之の比率の変化 ${ }^{25}$

$\mathrm{A}$; 溶液中

$\mathrm{B}$; 赤血球膜に結合した状態

$\bigcirc$; スペルミン, $\triangle$; スペルミジン, $\square ;$ プ トレスシン

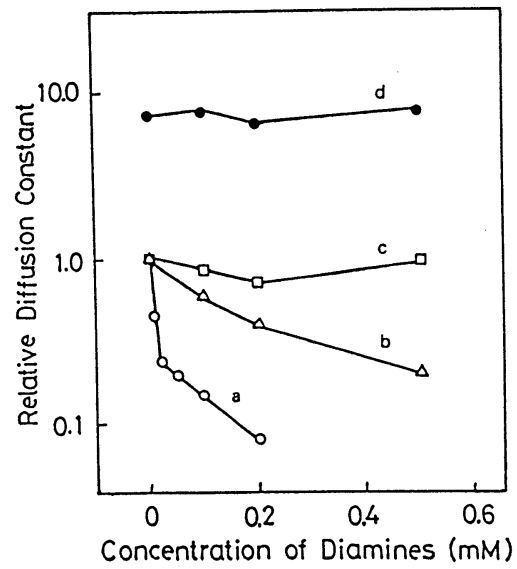

Fig. 9 バンド 3 の lateral motionに与えるポリア ミンの効果 ${ }^{25)}$

○; スペルミン $\triangle$; スペルミジン $\square ;$; プ トレスシンりはトリプシン処理ゴースト に，スペルミンを加えたとき (Fig.10参照)

体とを分ける (B). スペルミン, スペルミジンの存在は, 4 量体の比率を上げる。プトレスシンはほとんど影響を
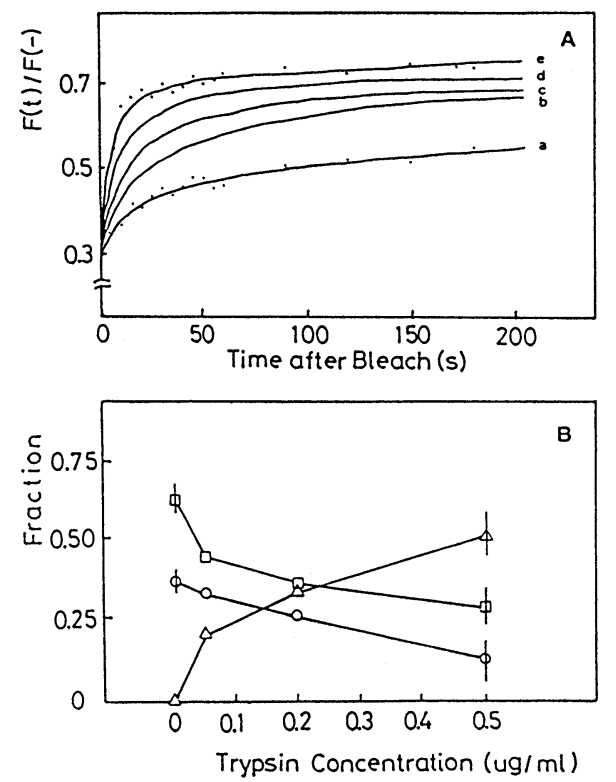

Fig. 10 バンド 3 の lateral motionにおける, 細胞 質側ドメインの役わり ${ }^{25}$

赤血球膜ゴーストをトリプシン処理すると, バンド 3 の細胞質側ドメインが切れて遊離 する.トリプシン濃度 $0.5 \mu \mathrm{g} / \mathrm{ml}$ で処理 $(0$ ${ }^{\circ} \mathrm{C}, 20$ 分間 ) したときには, ほとんどの心゙ ンド 3 が切れている. 0 $0.5 \mu \mathrm{g} / \mathrm{ml}$ のとき には, 末処理のバンド 3 とトリプシン処理 されたバンド 3 が混在している.

$\mathrm{A} ; \mathrm{FPR}$ カーブの変化 $\mathrm{a} ; 0, \mathrm{~b} ; 0.05, \mathrm{c} ; 0.1, \mathrm{~d} ; 0.2$, e $; 0.5$ $\mu \mathrm{g} / \mathrm{ml}$

$\mathrm{B} ; 3$ 成分の比率の変化

$\square$; immobile 成分, $\bigcirc ; 5.3 \times 10^{-11} \mathrm{~cm}^{2} /$ $\mathrm{s}$ の成分, $\triangle ; 4.0 \times 10^{-10} \mathrm{~cm}^{2} / \mathrm{s}$ の成分.

与えない，Aは，溶液中に执いて，精製したスペクトリ ン 4 量体を $37^{\circ} \mathrm{C}$ で 20 分間インキュベーションして 2 量 体に解離させる実験を行ったものである. スペルミン, スペルミジンを加えておくと, 解離が部分的に阻害され る.

バンド 3 の lateral mobilityは, ポリアミンを加える と変化する (Fig. 9). Mobile成分とimmobile 成分の 比率 ( $40 \% / 60 \%$ ) は影響を受けないが, mobile 成分の拡

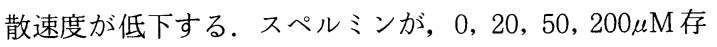
在するとき, $D_{T}=5.3 \times 10^{-11}, 1.3 \times 10^{-11}, 1.0 \times 10^{-11}$, $5 \times 10^{-12} \mathrm{~cm}^{2} / \mathrm{s}$ である. スペルミジンも同様の変化 を起こすが効果は小さい. プトレスシンはほとんど影響 を与えない。

スペクトリンの 4 量体の比率の増加とバンド 3 の拡散 
速度の低下との相関は, $\mathrm{NaCl}$ 濃度の変化に対してあみ られた。たとえば， $\mathrm{NaCl}$ 濃度を $10 \mathrm{mM}$ から $150 \mathrm{mM}$ へ と上げていくと，スペクトリンは 4 量体の比率が $35 \%$ か ら $50 \%$ (モル比)へと变化する. 乙のとき, mobile成分 の拡散定数は, $5.3 \times 10^{-11} \mathrm{~cm}^{2} / \mathrm{s}$ から $5 \times 10^{-12} \mathrm{~cm}^{2} / \mathrm{s}$ へと約 10 倍低下する.

これらの実験結果から，アンキリン free なバンド 3 の 拡散速度は，スペクトリンの会合状態により決定される ことが示唆される。

\section{3 バンド 3 の細胞質側ドメインと裏打ち構造体との} 相互作用

ゴーストを穏和な条件下でトリプシン処理すると，バ ンド 3 の細胞質側ドメイン (分子量 40k ダルトン) が切 れて遊離する、スペクトリン，アクチンなどは影響を受 けない(アンキリンは切机る可能性がある). トリプシ ン処理濃度を変えたときの FPR カーブは, Fig.10のよ うに変化する. eのカーブは, mobile成分 $70 \%, D_{T}=$ $4.0 \times 10^{-10} \mathrm{~cm}^{2} / \mathrm{s}$ である.また, b〜d の FPRカーブは, mobile 成分 1 つでは解析できない. 3 つの成分 $\left(D_{T}=\right.$ $4.0 \times 10^{-11}, 5.3 \times 10^{-11}$, immobile ) の相対的な比率の 変化 (B) は, immobile 成分, $D_{T}=5.3 \times 10^{-11} \mathrm{~cm}^{2} / \mathrm{s}$ の 成分ともに，細胞質側ドメインを失うと， $4.0 \times 10^{-10}$ $\mathrm{cm}^{2} / \mathrm{s}$ の速さで動くようになるてとを示している.また, トリプシン処理されたバンド 3 の拡散速度は，スペルミ ンの影響を受けない (Fig.9d).

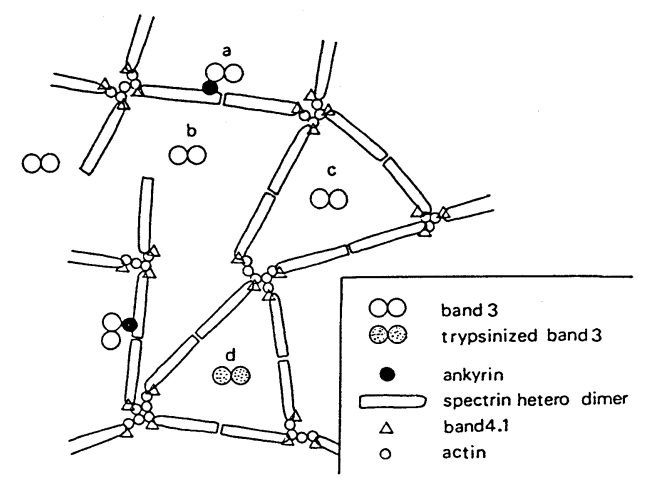
a. immobile
$<10^{-13} \mathrm{~cm}^{2} / \mathrm{s}$
b. mobile $5 \times 10^{-12} \sim 5 \times 10^{-11} \mathrm{~cm}^{2} / \mathrm{s}$
d. mobile $4 \times 10^{-10} \mathrm{~cm}^{2} / \mathrm{s}$

\section{4 裏打ち構造体による制御機構}

これまでに述べた実験結果から, 裏打ち構造体による バンド 3 の lateral motionの制御機構として, Fig. 11, 12のようなモデルが考えられる.ここでは, lateral motion を制限する機構が 2 種類存在する.

(1) direct linkage

(2) trapping

である. 網目の中に trapされると, その中での運動は自 由である (リン脂質層の粘性により決まる) が, 網目を

B.

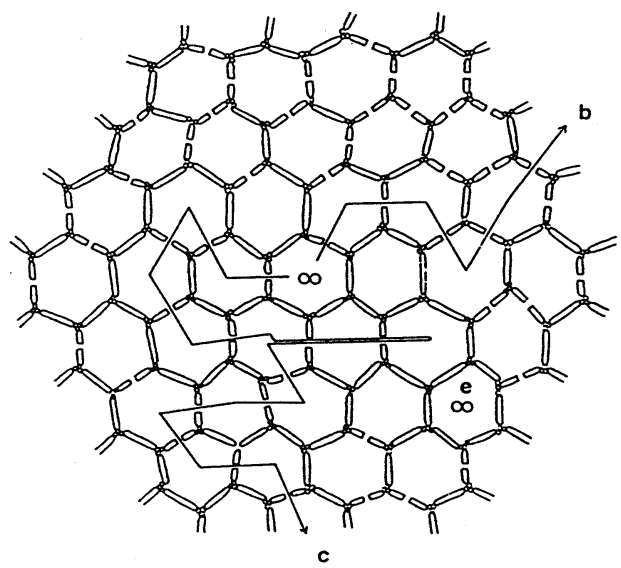

Fig.12 網目の中にtrapされたバンド $3(\infty)$ のlateral motion の模式図

網目を 6 角形で表わした。一辺はスペクト リン 4 量体 (つ)が形成するが，ところ どころ 2 量体 ( $\square \square)$ ) 亿解離している. b, c は, ある軌跡を表わす. eは, 網目の外 には出られない.

Fig.11 裏打ち構造体による, バンド 3 の lateral motion の制御機構のモデル26)

1. アンキリンと結合したバンド 3 は, 裏打 ち構造体と直接のつながりをむつことに より, 膜面上で動かない (a).

2. アンキリン freeなバンド 3 は, 細胞質 側ドメインにより,スペクトリン - バン ド 4.1 - アクチンがつくる網目の中に trapされる (b,c). 網目間の移動は, スペクトリン 4 量体が 2 量体に解離した とてろ(ゲート)を通ってのみ可能であ る (本文, Fig. 12 参照).

3. バンド 3 が, 細胞質側ドメインを失うと, 網目の影響を受けなくなる $(\mathrm{b})$. 
越えての移動は制限される，網目の大きさは，スペクト リン 4 量体の長さや網目構造物の電顕写真などからみる と，おおよそ直径 $200 \mathrm{~mm}$ ぐらいである. FPR 測定時の レーザースポットの大きさは半径 $0.8 \mu \mathrm{m}$ であるので, そ の距離の移動に要する時間は, 網目あたりの平均ゲート 数 (スペクトリン 4 量体が 2 量体に解離している比率) により影響を受ける。この様子を Fig. 12 亿模式的に示 した。

モデルに従えば，回転運動や網目内での拡散速度な ぞ微小な領域における運動性は, 網目の状態の影響を受 けないととが予想される。ポリアミンの添加や $\mathrm{NaCl}$ 濃 度の変化による, バンド 3 の回転運動への影響を, りん 光偏光解消法で調べた結果は, 乙の予想を支持するもの であった. Fig. 4 のりん光異方性の減衰カーブは, 前述 したように，回転運動には，速さの異なる少なくとあ 2 つ以上の成分が存在するてと，そのなかには，大きな制 限を受けているものが存在する $(\tau=1800 \mu$ 秒の成分と $\tau=\infty$ の成分) 乙とを示している. 乙れは，アンキリン と結合したあのや，大きな会合体をつくっているあのに 相当すると考えられる. $\mathrm{NaCl}$ 濃度を10〜150mM の範囲 で変えたとき, 減衰カーブには变化はみられなかった。

また，スペルミン，スペルミジン，プトレスシンを加え たときにあ基本的に同じ結果が得られた (Fig. 13). 図で は, 高濃度のと乙ろで遅い成分の回転相関時間が $2 \sim 3$ 倍大きくなっている $(\bigcirc, \triangle)$ が，乙机は会合体形成な どが起きているためと思われる，スペクトリンの 4 量体/ 2 量体の変化汇対応して lateral motionの速さが大き く変わる領域 $(0 \sim 0.1 \mathrm{mM})$ に扔いては, 回転運動の速さ はほとんど変化しない.

また，赤血球膜の他の内在性タンパク質グリコホリン の lateral motionは, FPR 法で調べると, 約 $90 \%$ が mobileであり, $10 \mathrm{mM} \mathrm{NaCl}$ 下で $D_{T}=7.5 \times 10^{-11} \mathrm{~cm}^{2} / \mathrm{s}$, $150 \mathrm{mM} \mathrm{NaCl}$ 下で $D_{T}=9.4 \times 10^{-12} \mathrm{~cm}^{2} / \mathrm{s}$ である. てれを, 上のモデルで説明すると, ほぼすべてのグリコ

膜 (リン脂質 2 分子層と内在性タンパク質)

相互作用

（直接的・間接的）

膜裏側の構造物

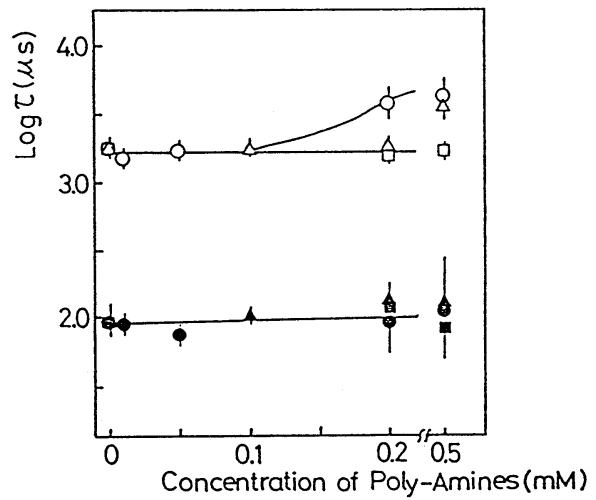

Fig. 13 バンド 3 の回転運動に与えるポリアミンの 効果 ${ }^{26)}$

りん光の異方性の減衰カーブ (Fig. 4)を式 [7] で解析し, パラメータ, $R_{1}, R_{2}, R_{3}$, $\tau_{1}, \tau_{2}$ の值を求めた. 回転緩和時間 $\tau_{1}(\bigcirc$ $\Delta \square), \tau_{2}(\boldsymbol{\Delta} \square)$ の変化をプロットし た. $R_{1} / R_{0}, R_{2} / R_{0}, R_{3} / R_{0}\left(R_{0}=R_{1}+\right.$ $\left.R_{2}+R_{3}\right)$ はほとんど变化しない。

○;スペルミン, $\triangle ;$;スペルミジン, $\square ; 7^{\circ}$ トレスシン

ホリン分子が網目の中に trapされ,スペクトリンの 4 量 体と 2 量体の比率に対応した速度で拡散していることに なる。

\section{4. おわりにーラテラル方向の構造の動的な変化}

人工膜に打ける膜タンパク質の動的挙動は, 主として リン脂質層の物性により決まる。一方, 細胞膜において は, 膜裏側にタンパク質の複重合体からなる構造物が存 在するが，乙の構造物は膜タンパク質と相互作用を行い， 膜タンパク質の動的挙動を人工膜に抢けるそれから異な らしめていると考えられる.赤血球膜を用いた研究から, その機構として, コンパートメンテーションとアンカー タンパク質の存在が示唆された (Fig.14).

赤血球膜に扔ける膜内粒子 ( IMP) の分布は, フリー ズフラクチャー法でみると, ランダムである。乙れにイ

\section{ラテラル方向の動的な変化}

膜タンパク質の分布状態の変化 会合体の大きさ 複合体形成

膜タンパク質の動きの変化 mobile $\rightleftarrows$ immobile 変換 速さの変化 
ンフルエンザウイルスを結合させ, 弱酸性下でインキュ ベーションすると, $4^{\circ} \mathrm{C}$ でIMP の凝集が起こる. このと き, 裏打ち構造体の形態が変化していることが認められ た.これは, 裹打ち構造体によるコンパートメンテーシ ョンのため, IMP の凝集が起こらない状態であったもの が, インフルエンザウイルスの影響でコンパートメンテ ーションが弱くなり, 広い範囲にあるIMPが1力所に集 まることができるようになったと考えられる.てのとき， バンド 3 のラテラル方向の拡散速度は大きく上昇してい た $\left(8 \times 10^{-10} \mathrm{~cm}^{2} / \mathrm{s}\right)^{36)}$.

アンキリンのようなアンカータンパク質の存在は, 膜 タンパク質に mobileな状態と immobile 状態とをむたら す. 赤血球膜においては, アンキリンの存在量がバンド 3 亿対して少なく, また, バンド 3 が会合体をつくる性 質をむっている. 乙のため, バンド 3 の会合状態の変化 は, mobile $\rightleftarrows$ immobile変換をむたらす. たとえば, バ ンド 3 が 8 量体を形成しているときには, すべてが immobile であろう. 会合状態が変化し，2 量体になると， 全体の $75 \%$ が mobile 乞変換する. 膜タンパク質の mobile $\rightleftarrows$ immobile 変換は, アンカータンパク質の生成・ 分解によるもののほかに, 流動性変化などで引き起こさ れる会合状態の変化により起こることが予想される.

これまで, 生体膜の動的構造の研究では, 膜を構成し ている個々の分子の動的状態が詳細に調べられてきた. その結果, 膜タンパク質や脂質のラテラル方向の拡散, 回転, リン脂質のアルキル鎖の屈曲運動, 膜タンパク質 表面付近での脂質分子の運動状態などについて多くの知 見が得られている. 一方，生体膜をラテラル方向になが めたとき, タンパク質や脂質の分布は均一ではない. ま た，それは動的な状態にあり，外界からの刺激・情報な どにより変化していると考えられる. 今後は, 個々の構 成分子の動的状態についてのてれまでの研究成果をあと にして, てのような「ラテラル方向のオーガニゼーショ ン」の変化の実態を明らかにしていくことあ必要であろ う.乙れは, ラテラル方向の拡散, 回転, 会合状態の変 化, 複合体形成などを個別に測定し, その結果を相互に 関連づけていくことで可能になると考えられる.

本綜説のもとになる研究は, 京都大学理学部生物物理 学教室 大西研究室にて行ったものです.

\section{文献}

1) Singer, S. J., Nicolson, G. L.: Science, 175, 720 (1972)
2) Saffman, P. G., Delbrück, M.: Proc.Natl.Acad. Sci. USA, 72, 3111 (1975)

3) Axelrod, D., Koppel, D. E., Schlessinger, J., Elson, E. L., Webb, W. W.: Biophys.J., 16, 1055 (1976)

4) Koppel, D. E., Axelrod, D., Schlessinger, J., Elson, E. L., Webb, W. W.: Biophys.J.,16, 1315 (1976)

5) Jacobson, K., Elson, E., Koppel, D., Webb, W.: Fed. Proc., 42, 72 (1983)

6) Chang, C.-H., Takeuchi, H., Ito, T., Machida K., Ohnishi, S.: J. Biochem., 90, 997 (1981)

7) Popp, C. A., Hyde, J.S.: Proc. Natl. Acad. Sci. USA, 79, 2559 (1982)

8) Feix, J. B., Popp, C. A., Venkataramu, S. D., Beth, A. H., Park, J. H., Hyde, J.S.: Biochemistry, 23, 2293 (1984)

9) Kunicki, T. J., Nugert, D. J., Pitrowicz, R. S., Lai, C.-S.: Biochemistry , 25, 4979 (1986)

10) Cherry, R. J.: Methods in Enzym. LIV 47 (1978)

11) Zidovertzki, R., Bartholdi, M., Arndt-Jovin, D., Jovin, T. M. : Biochemistry, 25, 4379 (1986)

12) Berliner, L. J. (edt.): "Spin Labeling, Theory and Applications" Academic Press, New York (1976)

13）辻 明彦, 大西俊一：化学と生物, 22, 178 (1984)

14) Thomas, D. D., Dalton, L. R., Hyde, J. S. : J. Chem. Phys., 65, 3006 (1976)

15）楠自明弘, 大西俊一：化学の領域, 33, 791 (1979)

16) Sakaki, T., Tsuji, A., Chang, C.-H., Ohnishi, S.: Biochemistry, 21, 2366 (1982)

17) Nigg, E. A., Born, C., Girardet, M., Cherry, R. J. : Biochemistry, 19, 1887 (1980)

18) Gut, J., Richter,C., Cherry, R. J., Winterhalter, K. H., Kawato, S.: J. Biol. Chem., 257, 7030 (1982)

19) Kusumi. A., Sakaki, T., Yoshizawa, T., Ohnishi, S. : J. Biochem., 88, 1103 (1980)

20) Muhlebach, T., Cherry, R. J. : Biochemistry, 24, 975 (1985)

21) Sheetz, M. P., Schindler, M., Koppel, D. E. : Nature, 285, 510 (1980)

22) Schindler, M., Koppel, D. E., Sheetz, M. P. : Proc. Natl. Acad. Sci. USA, 77, 1457 (1980)

23) Golan, D. E., Veatch, W. : Proc. Natl. Acad. Sci. USA, 77, 2537 (1980)

24) Nigg, E. A., Cherry, R. J. : Proc. Natl. Acad. Sci.USA, 77, 4702 (1980)

25) Tsuji, A., Ohnishi, S. : Biochemistry, 25, 6133 (1986)

26) Tsuji, A., Kusumi, A., Merkle, H., Ohnishi, S. : Biochemistry, submitted

27) Byers, T. J., Branton, D. : Proc. Natl. Acad. Sci. USA, 82, 6153 (1985)

28) Schen, B. W., Josephs, R., Steck, T. L. : J. Cell 
Biol., 102, 997 (1986)

29) Lux, S. E. : Nature, 281, 426 (1979)

30) Repasky, E. A., Granger, B.L., Lazarides, E. : Cell, 29, 821 (1982)

31) Spiegel, J. E., Beardsley, D. S., Southwick, E. S., Lux, S.: J. Cell Biol., 99, 886 (1984)

32) Bennett, V., Davis, J. : Proc. Natl. Acad. Sci. US A, 78, 7550 (1981)

33) Bennett, V., Stenbuck, P. J. : Nature, 280, 468 (1979)

34) Ungewickell, E., Gratzer, W. : Eur. J. Biochem., 88, 379 (1979)
35) Liu, S.-C., Palek, J.: Nature, 285, 586 (1980)

36) Yoshimura, A., Yamashina, S., Ohnishi, S. : Exp. Cell Res., 160, 126 (1985)

37) Rigler, R., Ehrenberg, M.: Q. Rev. Biophys., 6, 139 (1973)

38) Pappert, G., Schubert, D. : Biochim. Biophys, Acta, 730, 32 (1983)

39) Bittman R., Sakaki, T., Tsuji, A., Devaux, P, F., Ohnishi, S.: Biochim. Biophys. Acta, 769, 85 (1984)

40) Peters, R., Cherry, R. J.: Proc. Natl.' Acad. Sci. USA, 79, 4317 (1982)

\section{Clostridium butyricumにおける脂質二重層の安定化制御：エーテル脂質 の多形相動態の研究}

\section{Regulation of Bilayer Stability in Clostridium butyricum: Studies on the Polymorphic Phase Behavior of the Ether Lipids}

H. Goldfine, N. C. Johnston, J. Mattai and G. G. Shipley: Department of Microbiology, University of Pennsylvania, School of Medicine, Philadelphia, Pennsylvania 19104-6076;

Biophysics Institute, Boston University School of Medicine, Boston, Massachusets 02118

Biochemistry 26, 2814-2822 (1987)

Clostridium butyricum は膜の主要なリン脂質とし てホスファチジルエタノールアミン $(\mathrm{PE})$, エーテル脂質 であるプラズメニルエタノールアミン (PlaE) および PlaEのグリセロール骨格の 1 位にある脂肪アルコール のビニルエーテル部分にグリセロールがアセタール結合 したあの (Gly-PlaE) をあつ. ビオチン不在下で培地に cis 不飽和脂肪酸を添加して培養すると膜りン脂質の側 鎖にこの脂肪酸が取り込まれるとともに Gly-PlaEの割 合が増加する，乙こでは，不飽和脂肪酸型 PEが容易に 非二重層構造に移転する性質をあつのに対して, GlyPlaEが膜を二重層構造に安定化させる役割を果すこと を報告している.

オレイン酸を含みビオチンを含まない培地でC. butyr iucm ATCC 19398 を嫌気的に培養し，そのリン脂質画 分を $\mathrm{PE}$ と $\mathrm{PlaE}$ を含む分画および Gly-PlaEの分画に分 離した. 脂肪酸組成を分析したとてろ 92 から $98 \%$ がオ レイン酸またはその誘導体であるシクロプロパン脂肪酸 に置換していた。 $147.5 \mathrm{MHz}$ の ${ }^{31} \mathrm{P}-\mathrm{NMR}$, 走查示差熱 量測定 (昇温降温速度 $5^{\circ} \mathrm{C} / \mathrm{min}$ ), $\mathrm{X}$ 線回折により液晶-
結晶の相転移温度, ラメラ相とへキサゴナル I相の間の 相転移温度を調べた. 昇温測定で PE+PlaE分画は -1.9 ${ }^{\circ} \mathrm{C}$ に $\triangle H=3.8 \mathrm{kcal} / \mathrm{mol}$ の転移を示したのに対して, Gly-PlaE 分画は $3.5^{\circ} \mathrm{C}(\triangle H=0.6 \mathrm{kcal} / \mathrm{mol})$ と $16.1^{\circ} \mathrm{C}$ $(\triangle H=9.0 \mathrm{kcal} / \mathrm{mol})$ に転移を示した. NMR 測定から $\mathrm{PE}+\mathrm{PlaE}$ 分画では $0^{\circ} \mathrm{C}$ でラメラ相とへキサゴナル II 相 が共存するスペクトルが得られたのに対して, Gly-PlaE 分画では $50^{\circ} \mathrm{C}$ までラメラ相のスペクトルであった。乙 の結果はX線による回折パターン上でも同一であった。 一方, 天然の卵黄 $\mathrm{PE}$ は $20^{\circ} \mathrm{C}$ で, 合成の DOPEは $15-$ $20^{\circ} \mathrm{C}$ でほぼ完全にへキサゴナルII相に転移しているが, Gly-PlaEを 3 分の 1 含む混合系にすると卵黄 PEで $40^{\circ} \mathrm{C}$ まで DOPEで $25^{\circ} \mathrm{C}$ までラメラ相が安定化された。 Gly-PlaEが脂質を二重層に安定化させるのはsn-1 鎖に アセタール結合したグリセロール基が極めて親水性が強 く，水之接触しようとするためと考えられる．乙のため ラメラ相からへキサゴナルII 相への相転移温度は $\mathrm{PlaE}$ から Gly-PlaE になることで $45^{\circ} \mathrm{C}$ 以上も上昇する。

(名古屋大学工学部 大木和夫) 